\title{
NÍVEL DE PREPARAÇÃO PARA LIDERANÇA, SOB A PERSPECTIVA DOS ACADÊMICOS DE CIÊNCIAS CONTÁBEIS DA UNEMAT E UNIC EM TANGARÁ DA SERRA - FORMANDOS 2013/2
}

\author{
Ana Caroline Bastos Casagrande ${ }^{1}$ \\ Ivon de Mello Trelha ${ }^{2}$
}

\begin{abstract}
RESUMO
Em um cenário de constante crescimento do setor contábil, cada vez mais o mercado exige dos profissionais recém-formados perfis e características diferenciadas, e a liderança vem sendo uma característica de suma importância, uma vez que o contador passa de funções meramente operacionais para o contato direto com o cliente, exercendo influência na tomada de decisões, e mantendo o controle das variáreis contábeis. Este estudo aborda uma pesquisa entre os formandos de Ciências Contábeis da Universidade do Estado de Mato Grosso e da Universidade de Cuiabá de Tangará da Serra - MT, com o intuito de questionar a preparação dos acadêmicos de Ciências Contábeis como líderes no mercado de trabalho e suas perspectivas, além de, verificar as pretensões após a conclusão do curso, a preparação para assumir uma equipe, e a responsabilidade desta preparação, bem como analisar a grade destas universidades com uma universidade que seja o modelo ideal a ser seguido. As metodologias usadas foram às pesquisas: bibliográfica e descritiva buscando fundamentação teórica, e a qualitativa, quantitativa e pesquisa de campo para o levantamento dos dados, realizados através de aplicação de questionários aos formandos do curso de Ciências Contábeis da UNEMAT e da UNIC de Tangará da Serra - MT. Diante do exposto, baseado nos dados levantados, verificou-se que grande parte dos acadêmicos do oitavo semestre afirma que não sentia preparados para serem gestores e ocupar cargos de liderança, eles também julgaram que a universidade não os preparou para este tipo de desafio no mercado de trabalho. Ao analisar a grade destas universidades em questão com a de uma universidade modelo, pode-se verificar que elas estão desatualizadas em relação a suas grades curriculares, porém a UNEMAT vem passando por mudanças positivas nestes aspectos, para em 2014 passar a vigorar uma nova grade curricular que tentará se assemelhar a de uma universidade que seja modelo em todo o país.
\end{abstract}

Palavras chaves: Liderança. Ciências Contábeis. Acadêmicos.

\section{INTRODUÇÃO}

Na visão da grande maioria, o profissional contábil possui atribuições meramente operacionais, com intuito de produzir escriturações, demonstrações e fluxos gráficos, a fim de evitarem-se multas. Com o decorrer do tempo, houve uma mudança na postura do contador, de um profissional extremamente operacional, passou a exercer a função de consultor. $\mathrm{O}$ mercado de trabalho encontra-se cada vez mais competitivo, exigindo que os profissionais tenham uma visão estratégica, gestora e de liderança, na busca do sucesso na carreira.

\footnotetext{
${ }^{1}$ Acadêmica do curso de Ciências Contábeis da UNEMAT - Campus de Tangará da Serra, e-mail: caroolcasagrande@hotmail.com

${ }^{2}$ Professor do curso de Ciências Contábeis da UNEMAT - Campus de Tangará da Serra, e-mail: nnovi98@uol.com.br
} 
Nível de preparação para liderança, sob a perspectiva dos acadêmicos de ciências contábeis da UNEMAT

e UNIC em Tangará da Serra - formandos 2013/2

Ana Caroline Bastos Casagrande

Ivon de Mello Trelha

Durante todo o período acadêmico são cursadas disciplinas que de forma direta ou indiretamente auxiliam o estudante a lidar com pessoas e atuar em cargos de gestão e liderança. Porém, será que os acadêmicos do oitavo semestre do curso de ciências contábeis se sentem preparados para assumirem um cargo de liderança no mercado de trabalho?

Diante desta problemática se fez necessário a realização desta pesquisa com os formandos de Ciências Contábeis da Universidade Estadual do Mato Grosso e da Universidade de Cuiabá em Tangará da Serra - MT, com o objetivo geral de verificar na perspectiva dos acadêmicos do curso de ciências contábeis a preparação como líderes. Tendo como objetivos específicos verificar as pretensões após a conclusão do curso, julgar nesta mesma perspectiva de quem é a responsabilidade da preparação do acadêmico para este tipo de desafio, e comparar as grades destas universidades com a de uma universidade que seja referência em todo o país.

\section{FUNDAMENTAÇÃO TEÓRICA}

\subsection{Perfil Profissional do Contador}

Gondin (2002) ressalta que o desenvolvimento científico e tecnológico, base fundamental da globalização, aumenta a complexidade do mercado de trabalho e passa a exigir um profissional com competência para lidar com um número expressivo de fatores. Este perfil profissional desejável está alicerçado em três grandes grupos de habilidades:

a) As cognitivas, comumente obtidas no processo de educação formal (raciocínio lógico e abstrato, resolução de problemas, criatividade, capacidade de compreensão, julgamento crítico e conhecimento geral);

b) As técnicas especializadas (informática, língua estrangeira, operação de equipamentos e processos de trabalho);

c) As comportamentais e atitudinais - cooperação, iniciativa, empreendedorismo, motivação, responsabilidade, participação, disciplina, ética e a atitude permanente de aprender a aprender.

A autora comenta que a ênfase numa formação generalista e a ampliação das probabilidades de experiência prática durante o curso superior são avaliadas como opções para atender a exigência de um perfil multiprofissional e proporcionar a maturidade pessoal e a identidade profissional, necessárias para agir em situação de imprevisibilidade, realidade a que estão sujeitas as organizações atuais. 
Nível de preparação para liderança, sob a perspectiva dos acadêmicos de ciências contábeis da UNEMAT e UNIC em Tangará da Serra - formandos 2013/2

Ana Caroline Bastos Casagrande

Ivon de Mello Trelha

Kounrouzan (2011), em seu artigo, enfatiza que o profissional contábil entra numa nova era, mais atualizada, mais dinâmica, mais inovadora e mais exigente. Cabem aos profissionais a responsabilidade na maximização da utilização das informações contábeis e todo o trabalho de procurar atender aos diferentes usuários desta informação. Não pode deixar que a contabilidade seja apenas um retrato histórico da situação passada da entidade.

Iudícibus (1991) frisa que, para seu crescimento profissional e como cidadão, o contador deve manter-se atualizado não apenas com as novidades de sua profissão, mas de forma mais ampla, interessar-se pelos assuntos econômicos, sociais e políticos que tanto influem no cenário em que se desenrola a profissão.

Zanluca (2013) corrobora com os autores acima, quando menciona que o contabilista precisa conhecer e utilizar-se da gestão de pessoas, além de técnicas de administração. Não pode ficar alheio ao mundo que o cerca, e precisará ler continuamente, tornando-se um autodidata por excelência. Precisam ser éticos, inovador e criador, desenvolvendo também sua capacidade de adaptação, pois mudanças fazem parte do cenário empresarial e corporativo.

O contador não pode ficar limitado à execução da função, deve sim, estar sempre preparado para participação na tomada de decisão, propendendo identificar e corrigir as dificuldades e adversidades que surgem ao longo do caminho, através de ações empreendedoras baseadas nas informações geradas pela contabilidade (AQUINO, 2010).

Ele deve estar no centro e na liderança deste processo, pois, do contrário, seu lugar vai ser ocupado por outro profissional. O contador deve saber participar com as outras áreas da empresa para tanto, não pode ficar com os conhecimentos restritos aos temas contábeis e fiscais (NASI, 1994).

\subsection{Liderança}

Segundo Fachada (1998) a liderança é um controle interpessoal exercida em determinada situação através do método de comunicação humana, com vista à comunicação de determinados objetivos. 
Nível de preparação para liderança, sob a perspectiva dos acadêmicos de ciências contábeis da UNEMAT e UNIC em Tangará da Serra - formandos 2013/2

Ana Caroline Bastos Casagrande

Ivon de Mello Trelha

Coelho (2009) conceitua liderança como uma competência de caráter relacional, ou seja, pressupõe uma relação entre duas ou mais pessoas baseadas no exercício da influência. O princípio é despertar o desejo, o interesse e o entusiasmo no outro a fim de que adote procedimentos ou cumpra tarefas.

Maxwell (2008) afirma que a liderança é feita de dentro para fora. Você não pode convencer uma pessoa se não conhece a si mesmo. Esse talvez seja o grande desafio dos líderes e, ao mesmo tempo, o primeiro passo de quem ainda não tem uma equipe - lidere a si mesmo, convença-se a enfrentar desafios e melhorar profissionalmente a cada dia.

Para que haja sucesso na empresa, é preciso que os objetivos da gestão estratégica de pessoas estejam claros e definidos. O que vai garantir a qualidade nas ações desenvolvidas é a motivação dos colaboradores. Desenvolver e estimular a qualidade de vida vem sendo um dos grandes desafios da atualidade em várias instituições e também nas próprias pessoas, visando além de produtividade, o bem estar social que a pessoa merece. (SOVIENSKI, STIGAR, 2008).

Diante das discussões dos autores, percebe-se que o gestor de pessoas ou líder, deve passar confiança para vossa equipe, os mantendo sempre motivados, de forma que todos busquem um objetivo em comum, que é o sucesso, tanto da empresa, como o profissional de cada um. Dessa forma podemos demonstrar algumas diferenças existentes entre os gerentes e o lideres, conforme tabela abaixo:

Quadro 01 - Diferença entre gerente e líderes

\begin{tabular}{|l|l|}
\hline \multicolumn{1}{|c|}{ GERENTES } & \multicolumn{1}{c|}{ LÍDERES } \\
\hline Prioriza estrutura e sistemas & Prioriza pessoas \\
\hline Mantém & Desenvolve \\
\hline Controla & Compartilha \\
\hline Administra & Inova \\
\hline Visão de Curto Prazo & Perspectiva de futuro \\
\hline Faz as coisas direito & Faz as coisas certas \\
\hline
\end{tabular}

Fonte: LIMA (2010, pag. 6)

\subsection{Competências e Habilidades de um Líder}

Dutra, Hipólito \& Silva (1998) conceituam a competência como sendo a aptidão da pessoa em provocar resultados dentro do escopo organizacional. 
Nível de preparação para liderança, sob a perspectiva dos acadêmicos de ciências contábeis da UNEMAT

e UNIC em Tangará da Serra - formandos 2013/2

Ana Caroline Bastos Casagrande

Ivon de Mello Trelha

Segundo Ceccon (2011) a gestão de competências é uma forma avançada de administrar pessoas, sendo que sua sustentação está nos conhecimentos requeridos pela empresa para que seus objetivos sejam alcançados e na maneira como esses conhecimentos são disseminados entre os profissionais. Entre os principais objetivos da adoção de uma gestão por competências para Boog (2002), destaca-se:

- Entender, organizar e disseminar os conhecimentos ligados aos negócios e as estratégias da empresa;

- Ser o instrumento de comunicação de mensagens de atitude, conhecimentos e habilidades esperadas de cada empregado;

- Formar uma base de dados sustentável e confiável para as avaliações de desempenho;

- Servir como valiosa fonte de informação para as necessidades de treinamento, planos de sucessão, carreira, seleção e remuneração;

- Comprometimento de líder na gestão efetiva e no desenvolvimento da sua equipe;

- Transparência nas relações internas.

Para Ruano (2003) a gestão de competências está diretamente ligada à área estratégica da empresa, se constituindo em um recurso importante para a gestão de organização, tendo como consequência uma atuação voltada para resultado e fornecendo suporte para o cumprimento dos objetivos e metas organizacionais. Segundo Dutra (2001), a gestão de pessoas tem como função o estímulo e o envolvimento dos funcionários. Para tanto, a gestão de competência pode ser considerada um instrumento poderoso na efetividade deste processo.

Para Ceccon (2011) usar o conhecimento de forma adequada é o que chamamos de "habilidade". Algumas pessoas acumulam muitas informações teóricas e têm dificuldade de abri-lo para uso. Com o tempo, as informações são esquecidas e ninguém se beneficiou do conteúdo. As habilidades precisam ser demonstradas na prática. O gerente-líder, além de ser bom, precisa demonstrar que é bom através de ações. De nada adianta colecionar cursos, leituras e informações em geral, se estas não são úteis e trazem algum benefício para a coletividade na qual o profissional está inserido.

\subsection{Responsabilidade das Universidades na Formação Acadêmica}

A Lei de Diretrizes e Base da Educação Nacional, No 9.394, de 20 de dezembro de 1996, estabelece em seu Artigo 43 que a educação superior tem por finalidade: 
Nível de preparação para liderança, sob a perspectiva dos acadêmicos de ciências contábeis da UNEMAT e UNIC em Tangará da Serra - formandos 2013/2

Ana Caroline Bastos Casagrande

Ivon de Mello Trelha

I - estimular a criação cultural e o desenvolvimento do espírito científico e do pensamento reflexivo;

II - formar diplomados nas diferentes áreas de conhecimento, aptos para a inserção em setores profissionais e para a participação no desenvolvimento da sociedade brasileira, e colaborar na sua formação contínua;

III - incentivar o trabalho de pesquisa e investigação científica, visando o desenvolvimento da ciência e da tecnologia e da criação e difusão da cultura, e, desse modo, desenvolver o entendimento do homem e do meio em que vive;

IV - promover a divulgação de conhecimentos culturais, científicos e técnicos que constituem patrimônio da humanidade e comunicar o saber através do ensino, de publicações ou de outras formas de comunicação;

V - suscitar o desejo permanente de aperfeiçoamento cultural e profissional e possibilitar a correspondente concretização, integrando os conhecimentos que vão sendo adquiridos numa estrutura intelectual sistematizadora do conhecimento de cada geração;

VI - estimular o conhecimento dos problemas do mundo presente, em particular os nacionais e regionais, prestar serviços especializados à comunidade e estabelecer com esta uma relação de reciprocidade;

VII - promover a extensão, aberta à participação da população, visando à difusão das conquistas e benefícios resultantes da criação cultural e da pesquisa científica e tecnológica geradas na instituição.

Na formação acadêmica de ciências contábeis, segundo Kounrouzan (2011), são três os agentes envolvidos: a universidade, o professor e o aluno. A educação, como principal agente, é a chave para valorização profissional, corresponde a um processo inserido no contexto das relações e interesses entre as universidades, aluno e empresas, que determinam a formação social, onde se faz imprescindível priorizar os aspectos filosóficos, políticos, sociológicos e epistemológicos da educação contábil, propendendo à formação de um profissional consciente de sua missão histórica e preparado para agir em grupo.

A folha de São Paulo em parceria com o Ministério de Educação - MEC, fizeram uma pesquisa, o RUF - Ranking Universitário Folha 2013, ela analisa a qualidade das 192 instituições, que foram avaliadas na pesquisa, inovação, internacionalização, ensino e mercado.

Nos indicadores de pesquisas foram analisados: total de publicações, citações, citações por artigos, publicações por docente, citações por docentes, publicações em revistas nacionais 
Nível de preparação para liderança, sob a perspectiva dos acadêmicos de ciências contábeis da UNEMAT e UNIC em Tangará da Serra - formandos 2013/2

Ana Caroline Bastos Casagrande

Ivon de Mello Trelha

e recursos captados em agências estaduais e federais de fomento a ciência. Os indicadores de internacionalização consideraram citações internacionais por docentes, publicações em coautoria internacional e docentes estrangeiros. No indicador de inovação levou em conta o número de pedidos de patentes da universidade no Instituto Nacional da Propriedade Industrial de 2002 a 2011. No ensino houve avaliadores do MEC com avaliações de professores, verificaram-se professores com doutorado e com dedicação integral, e nota no ENADE (Exame Nacional de Desempenho dos Estudantes). E por fim o indicador de mercado de trabalho, com uma pesquisa com 1.681 responsáveis pela área de recursos humanos de empresas de todo o país nas 30 carreiras analisadas pelo RUF.

No ranking geral a Universidade de São Paulo recebeu o primeiro lugar dentre todas as instituições como universidade ideal, o que indica ser uma das melhores do Brasil, conforme figura abaixo:

Quadro 02 - Ranking Universitário Folha 2013

\begin{tabular}{|c|c|c|c|c|c|c|c|}
\hline $\begin{array}{c}\text { Ranking } \\
2013\end{array}$ & Universidade & Ensino & Pesquisa & Mercado & Inovação & $\begin{array}{c}\text { Interna- } \\
\text { cionalização }\end{array}$ & Nota \\
\hline $\mathbf{1}^{\mathbf{0}}$ & $\begin{array}{l}\text { Universidade de } \quad \text { São } \\
\text { Paulo (USP) }\end{array}$ & $3^{\circ}$ & $\mathbf{1}^{\mathbf{0}}$ & $\mathbf{1}^{\mathrm{o}}$ & $\mathbf{1}^{\mathbf{0}}$ & $2^{\circ}$ & 96,89 \\
\hline $2^{\circ}$ & $\begin{array}{l}\text { Universidade Federal do } \\
\text { Rio de Janeiro (UFRJ) }\end{array}$ & $4^{\circ}$ & $4^{\circ}$ & $2^{\circ}$ & $4^{\circ}$ & $3^{\circ}$ & 95,64 \\
\hline $3^{\circ}$ & $\begin{array}{l}\text { Universidade Federal de } \\
\text { Minas Gerais (UFMG) }\end{array}$ & $2^{\circ}$ & $6^{\circ}$ & $4^{\circ}$ & $3^{\circ}$ & $7^{\circ}$ & 94,90 \\
\hline $4^{\circ}$ & $\begin{array}{l}\text { Universidade } \\
\text { Rio Granderal do } \\
\text { Rio do Sul } \\
\text { (UFRGS) }\end{array}$ & $1^{\circ}$ & $5^{\circ}$ & $11^{\circ}$ & $5^{\circ}$ & $21^{\circ}$ & 94,58 \\
\hline $5^{\circ}$ & $\begin{array}{l}\text { Universidade Estadual de } \\
\text { Campinas (Unicamp) }\end{array}$ & $7^{\circ}$ & $2^{\circ}$ & $11^{\circ}$ & $2^{\circ}$ & $6^{\circ}$ & 94,27 \\
\hline
\end{tabular}

Fonte: Ranking Universitário da Folha 2013

\section{METODOLOGIA}

Para a elaboração deste trabalho, quanto ao método de abordagem, foram pesquisas bibliográficas, descritivas, qualitativas e quantitativas. Segundo Gil (2002, p. 50) “a pesquisa bibliográfica é desenvolvida a partir de material já elaborado, constituído principalmente de livros e artigos científicos". A pesquisa qualitativa, segundo Jung (2004, pág. 61) "admite a interferência dos valores do pesquisador e considera a existência de múltiplas realidades".

A pesquisa descritiva tem como objetivo principal a definição de características de determinada população (GIL, 2002). E a pesquisa quantitativa considera-se que tudo pode ser 
Nível de preparação para liderança, sob a perspectiva dos acadêmicos de ciências contábeis da UNEMAT

e UNIC em Tangará da Serra - formandos 2013/2

Ana Caroline Bastos Casagrande

Ivon de Mello Trelha

quantificável, podendo traduzir em números as opiniões e informações, sendo analisados e classificados através de questionários.

Quanto aos procedimentos foi utilizada a pesquisa de campo. Para Vergara (1997, p. 45) "o estudo de campo é o tipo de investigação realizada no local onde ocorre ou ocorreu um fenômeno ou que dispõe de elementos para explicá-lo. Pode incluir entrevistas, aplicação de questionários, testes de observação participação ou não".

Para as coletas de dados foram aplicados 42 questionários com múltipla escolha e questões abertas aos acadêmicos que estavam presentes nos dias 04 e 07 de outubro, sendo que 22 deles foram entregues aos formandos 2013/2 do curso de Ciências Contábeis da Universidade Estadual de Mato Grosso - UNEMAT, e os outros 20 foram entregues aos formandos 2013/2 do curso de Ciências Contábeis da Universidade de Cuiabá - UNIC.

Após a coleta, os dados foram analisados de forma que sejam extraídos percentuais que permitam a análise e comparação dos mesmos. A partir dai foram utilizados textos explicativos para discussão dos resultados, até mesmo com citação de alguns acadêmicos. Os dados foram apresentados também, através de quadros e figuras que possibilitam o entendimento do leitor.

Em seguida, foram analisadas as matrizes curriculares localizando disciplinas através das ementas que estavam ligadas diretamente ou indiretamente com o foco da pesquisa, e foram feitas comparações com a matriz da USP, que segundo dados extraídos do RUF 2013, é o modelo de universidade ideal. Além do que, analisou-se se houve mudanças positivas em relação ao tema proposto na nova matriz curricular da UNEMAT que passará a vigorar em 2014.

O estudo se limitou a estes levantamentos, de forma que em um futuro possa ser aprofundado com dados dos acadêmicos da USP, e acadêmicos da UNEMAT no ano de 2014, podendo assim, dar continuidade ao estudo, de forma que possa analisar se houve mudanças nas preparações dos acadêmicos com a nova matriz.

\section{RESULTADOS E DISCUSSÃO}

Este tópico demonstra através de quadros e figuras os resultados obtidos nos questionários que foram aplicados aos acadêmicos do $8^{\circ}$ semestre do curso de ciências contábeis, na UNEMAT - Universidade do Estado de Mato e na UNIC - Universidade de Cuiabá, em Tangará da Serra - MT. No total foram 42 questionários, sendo 22 na UNEMAT 
Nível de preparação para liderança, sob a perspectiva dos acadêmicos de ciências contábeis da UNEMAT e UNIC em Tangará da Serra - formandos 2013/2

Ana Caroline Bastos Casagrande Ivon de Mello Trelha

e 20 UNIC, quantidade esta relacionada com os acadêmicos que estavam presentes em sala quando os mesmos foram aplicados.

Foi questionado aos acadêmicos através de alternativas quais seriam as pretensões após a conclusão do curso de Ciências Contábeis e 50\% deles em ambas as universidades pretender atuar na àrea pública, através de concursos. Pode-se perceber também que na UNEMAT $18 \%$ pretendem trabalhar em escritórios contábeis, e na UNIC $20 \%$ não pretendem atuar em nenhum dos seguimentos que o curso de ciências contábeis oferece.

Figura 01 - Pretensões após conclusão do curso - UNEMAT

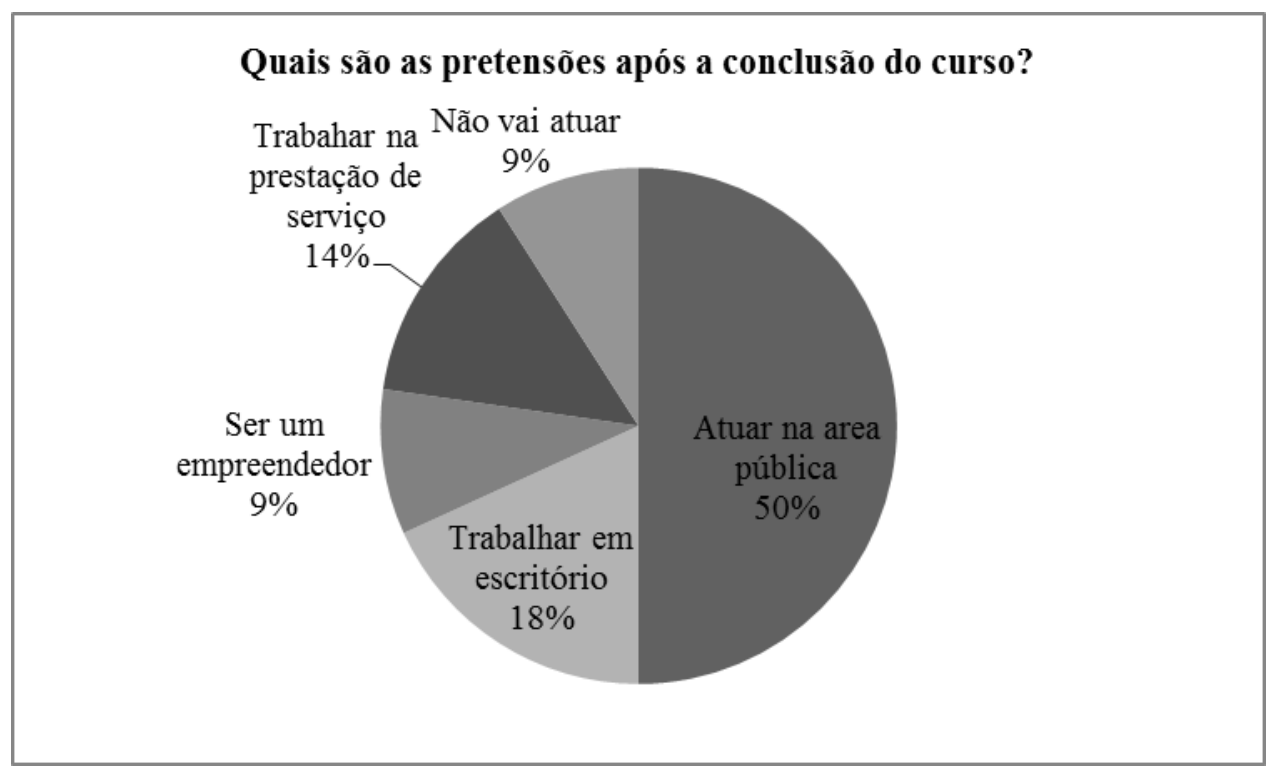

Fonte: Resultados da pesquisa

Figura 02 - Pretensões após conclusão do curso - UNIC

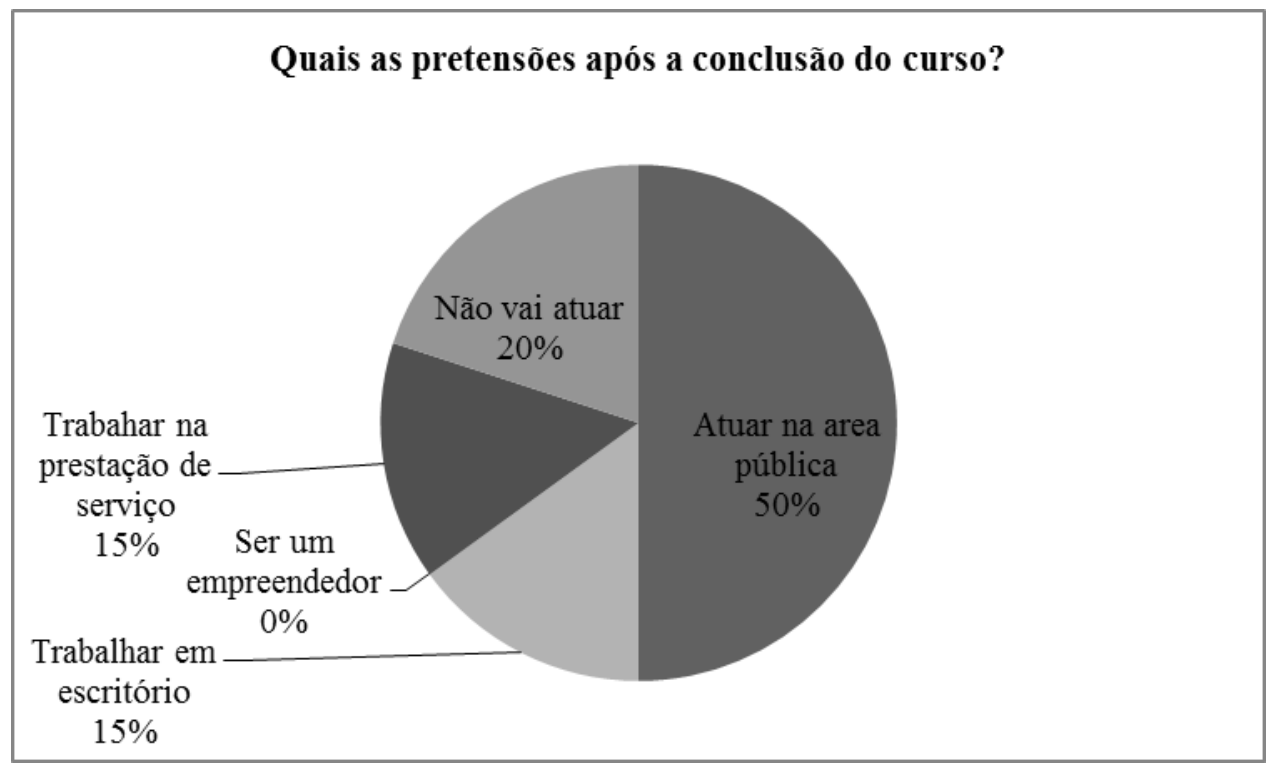

Fonte: Resultados da pesquisa 
Nível de preparação para liderança, sob a perspectiva dos acadêmicos de ciências contábeis da UNEMAT e UNIC em Tangará da Serra - formandos 2013/2

Ana Caroline Bastos Casagrande Ivon de Mello Trelha

Nas duas universidades conforme demonstrado nas figuras 05 e 06, um dos questionamentos feitos e também o foco do trabalho era na perspectiva dos acadêmicos a preparação para assumir um cargo de liderança/gestão, e pode-se perceber que da UNEMAT somente $27 \%$ se sentiam preparados para assumir uma equipe, já na UNIC $55 \%$ dos acadêmicos já se sentiam preparados para assumir um cargo de liderança, quantidade esta consideravelmente maior em relação à UNEMAT. Um acadêmico da UNIC que não se sentiam preparado e não pretendia atuar como líder, mencionou no questionário que prefere "seguir ordens e não ter que se responsabilizar pelo que os outros fazem".

Figura 03 - Preparação para liderança - UNEMAT

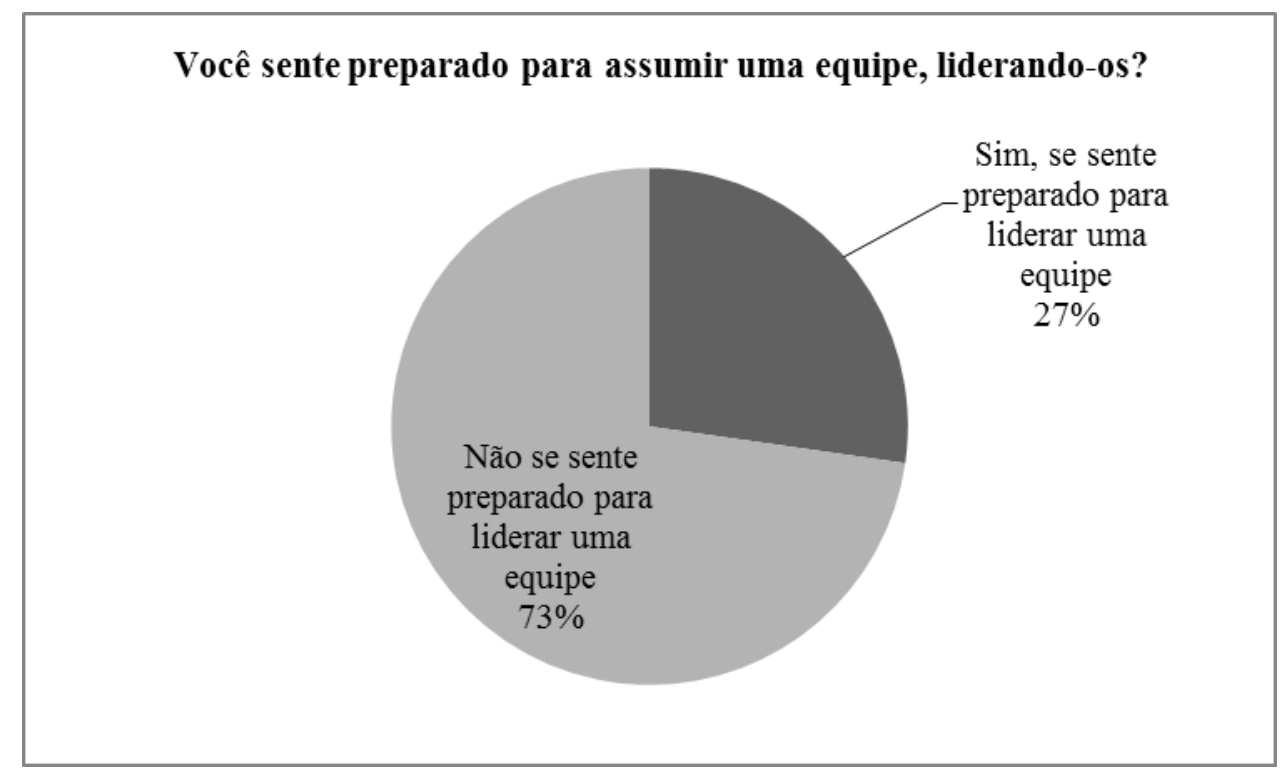

Fonte: Resultados da pesquisa

Figura 04 - Preparação para liderança - UNIC 
Nível de preparação para liderança, sob a perspectiva dos acadêmicos de ciências contábeis da UNEMAT e UNIC em Tangará da Serra - formandos 2013/2

Ana Caroline Bastos Casagrande

Ivon de Mello Trelha

Você sente preparado para assumir uma equipe, liderando-os?

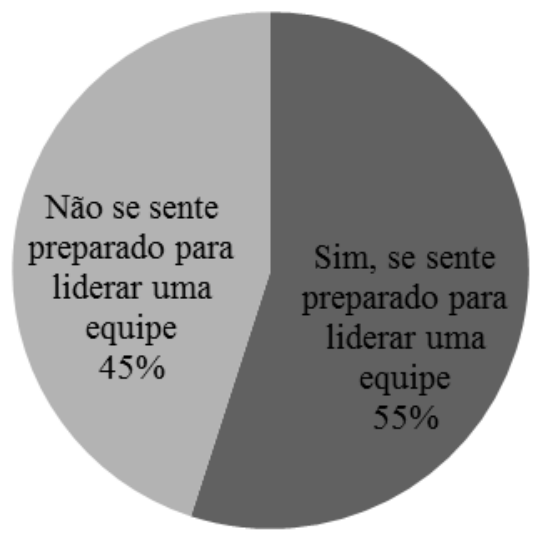

Fonte: Resultados da pesquisa

Aos acadêmicos que ainda não se sentiam preparados para assumir um cargo de liderança, foi questionado se eles julgavam que as universidades tinham responsabilidade nesta preparação, e grande maioria dos acadêmicos julgaram que as universidades (figura 07 e 08) não os prepararam para assumir este tipo de desafio no mercado de trabalho, correspondendo 64\% dos acadêmicos da UNEMAT e 70\% da UNIC.

Figura 05 - Preparação da universidade na opinião dos acadêmicos da UNEMAT

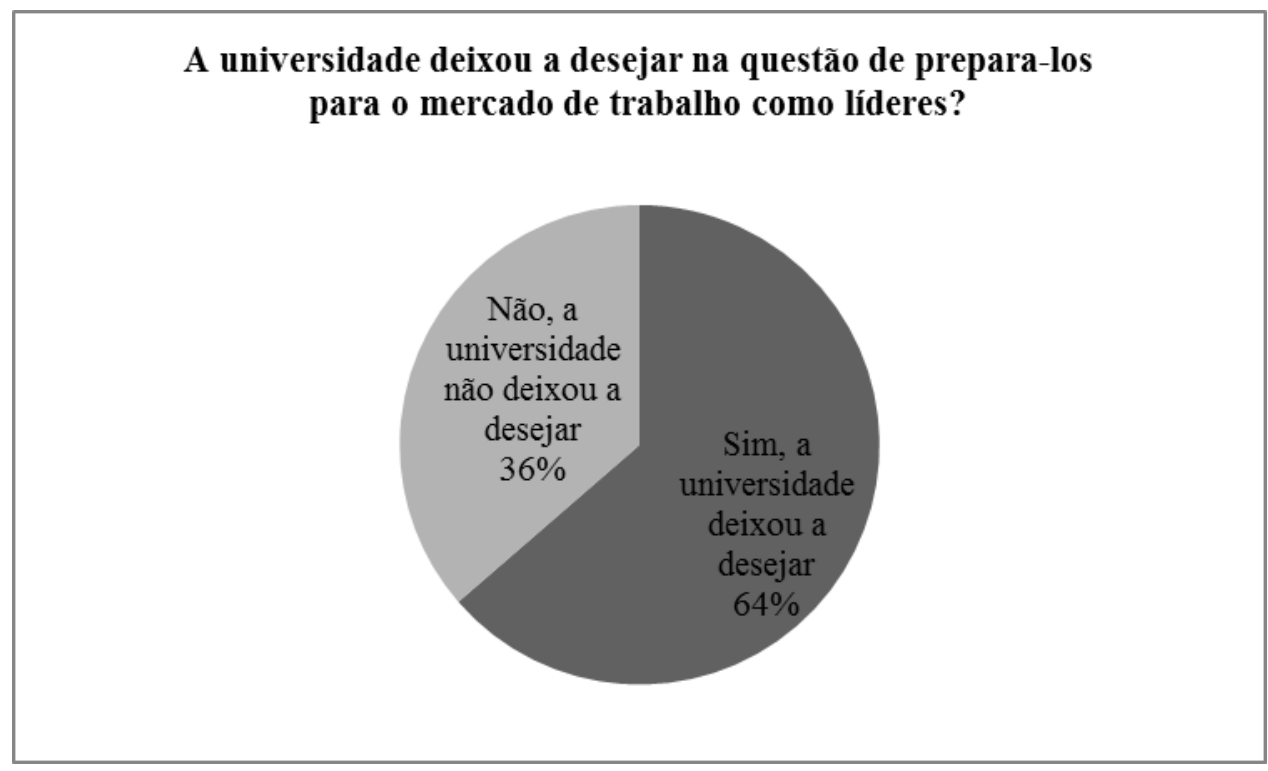

Fonte: Resultados da pesquisa

Figura 06 - Preparação da universidade UNIC 
Nível de preparação para liderança, sob a perspectiva dos acadêmicos de ciências contábeis da UNEMAT e UNIC em Tangará da Serra - formandos 2013/2

Ana Caroline Bastos Casagrande

Ivon de Mello Trelha

A universidade deixou a desejar na questão de prepara-los para o mercado de trabalho como líderes?

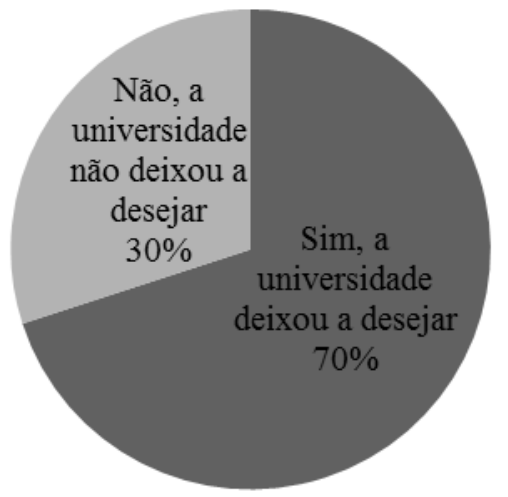

Fonte: Resultados da pesquisa

Dessa forma, foram identificados alguns aspectos que contribuíram para tal conforme figuras 09 e 10, em ambas as universidades a falta de aplicação na prática das disciplinas durante o período do curso foi o fator que mais teve impacto na deficiência de preparação dos acadêmicos como líderes para o mercado de trabalho após a conclusão do curso, representando 64\% dos acadêmicos na UNEMAT e 79\% na UNIC.

Figura 07 - Fatores que a universidade deixou a desejar - UNEMAT

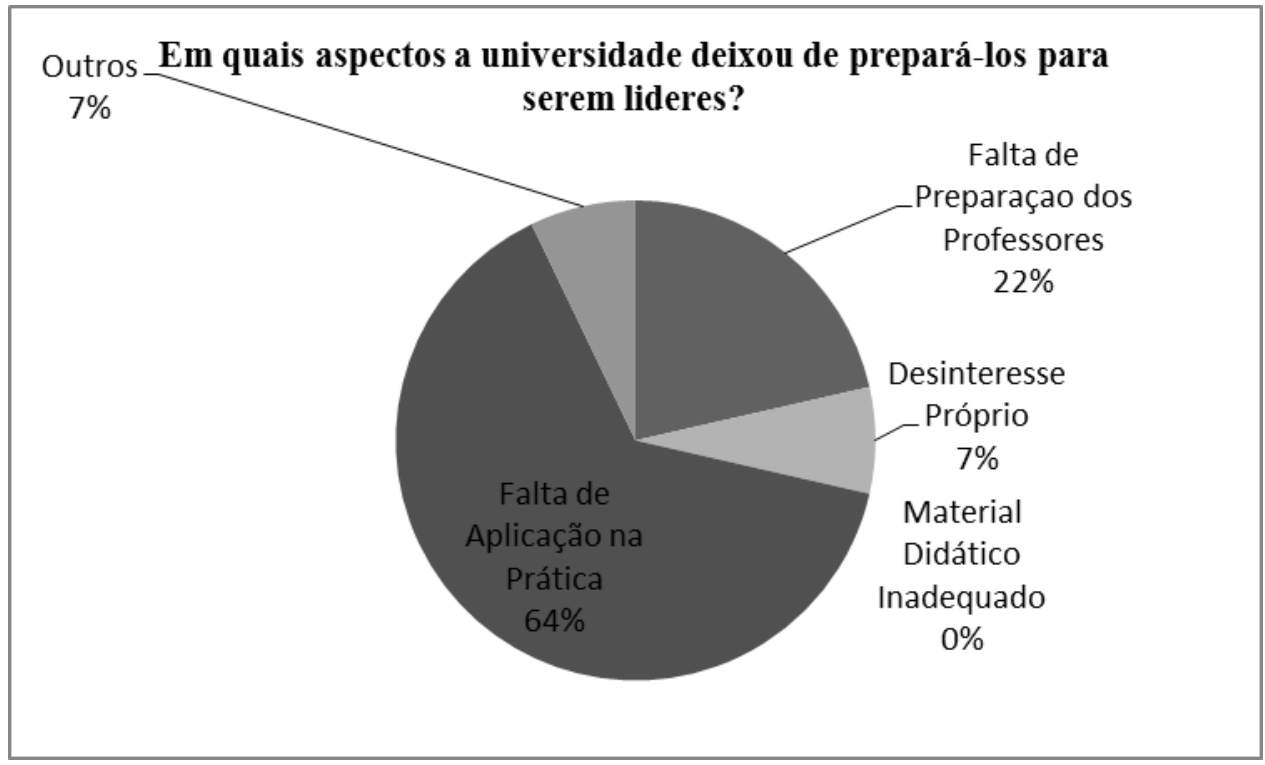

Fonte: Resultados da pesquisa 
Nível de preparação para liderança, sob a perspectiva dos acadêmicos de ciências contábeis da UNEMAT e UNIC em Tangará da Serra - formandos 2013/2

Ana Caroline Bastos Casagrande Ivon de Mello Trelha

Figura 08 - Fatores que a universidade deixou a desejar - UNIC

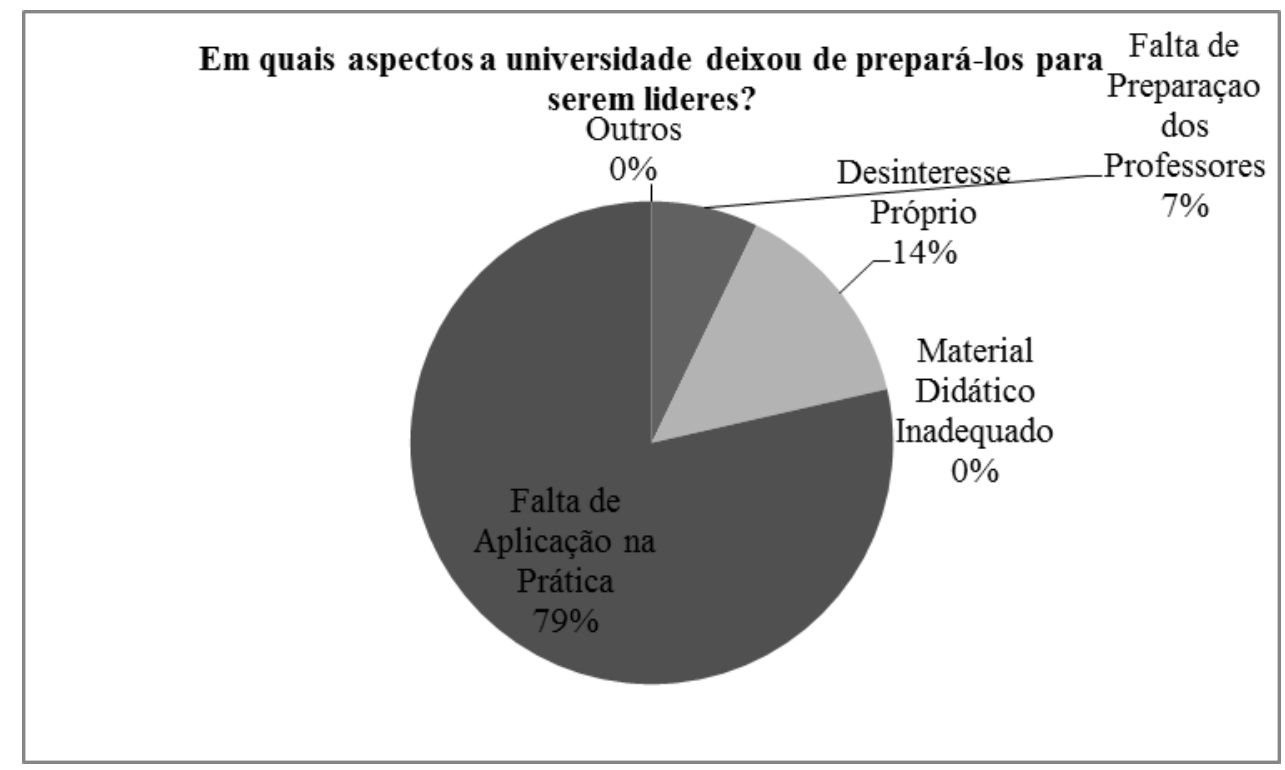

Fonte: Resultados da pesquisa

O perfil do novo contador não poder ficar limitado a performance de informante, ao contrário disso, deve estar preparado para tomar decisoes, visando identificar e corrigir as dificuldades e adversidades que surgem ao longo do caminho, através de ações pró-ativas, baseadas nas informações que são geradas pela contabilidade. Seguindo essa linha de raciocinio podemos identificar diversas qualidades, dentre algumas delas, fora questionado a mais importante nos dias de hoje, e tanto na UNEMAT, quanto na UNIC, o contador como tomador de decisão tem chamado mais atenção na perspectiva dos acadêmicos, sendo representado por $50 \%$ na UNEMAT e $40 \%$ na UNIC.

Figura 09 - Qualidades do Contador - UNEMAT 
Nível de preparação para liderança, sob a perspectiva dos acadêmicos de ciências contábeis da UNEMAT e UNIC em Tangará da Serra - formandos 2013/2

Ana Caroline Bastos Casagrande

Ivon de Mello Trelha

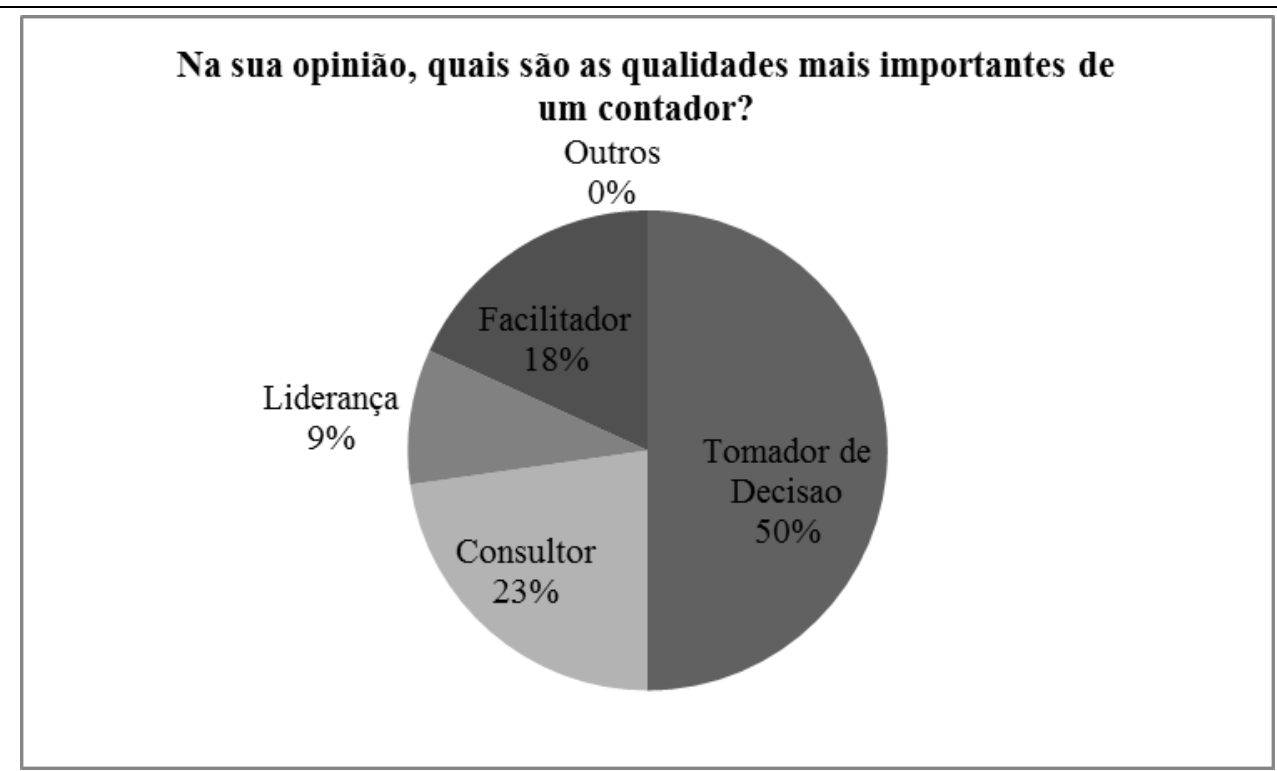

Fonte: Resultados da pesquisa

Figura 10 - Qualidades do Contador - UNIC

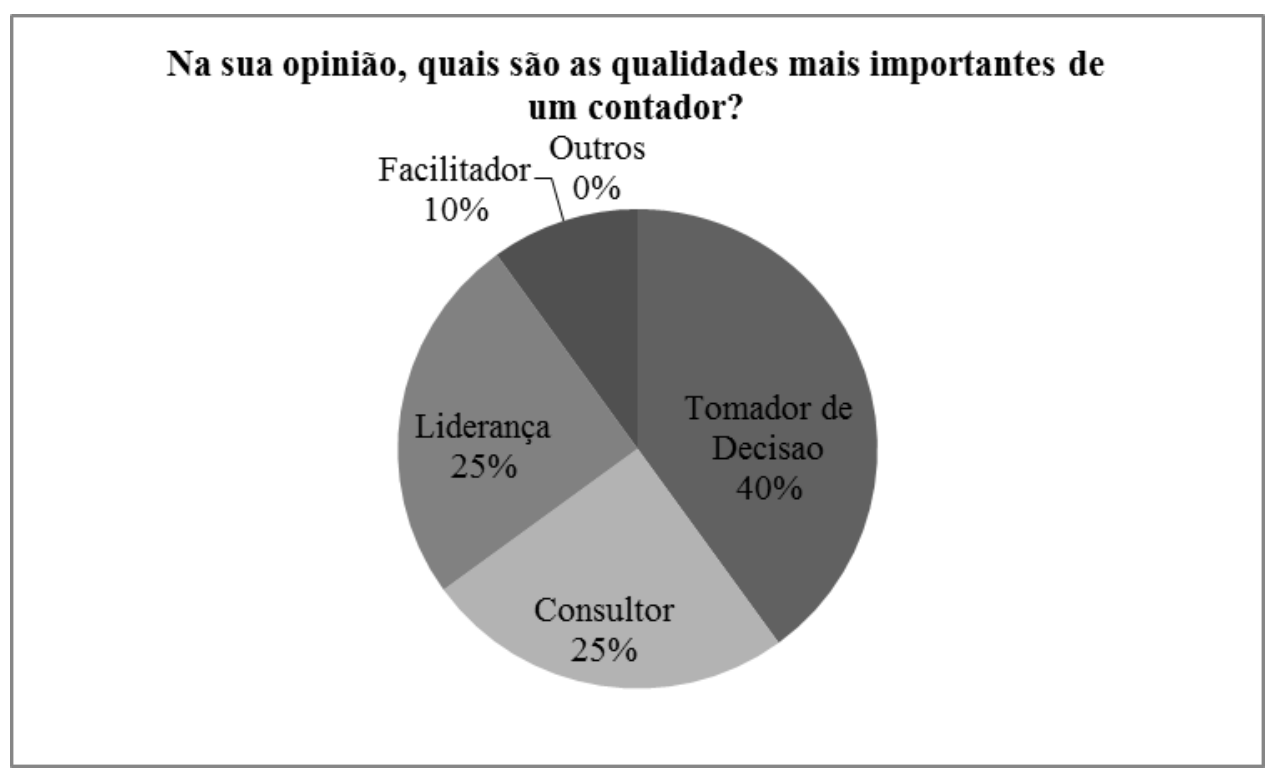

Fonte: Resultados da pesquisa

Partindo desse pressuposto o que o mercado de trabalho espera do contador em pleno século XXI é que ele seja um consultor, gestor, líder e tomador de decisões, que saiba discorrer dos assuntos e também saiba conduzir e desenvolver sua equipe. As maiorias dos acadêmicos das duas universidades também concordaram com esta afirmação e um deles da UNEMAT completou que "profissional deve saber do que está falando, passar segurança e posicionamento de liderança junto à equipe e os seus clientes", outro acadêmico também da UNEMAT citou que "não só a profissão de contador exige isso, o mercado de trabalho atual é Volume 3, Número 5 Revista UNEMAT de Contabilidade 
Nível de preparação para liderança, sob a perspectiva dos acadêmicos de ciências contábeis da UNEMAT

e UNIC em Tangará da Serra - formandos 2013/2

Ana Caroline Bastos Casagrande

Ivon de Mello Trelha

muito rigoroso e obriga tanto o contador como o administrador a estar preparado para ser um líder”.

Durante a análise dos resultados surgiu uma nova problemática em relação à falta de aplicação na prática das disciplinas. Na busca de tentar entender e complementar a pesquisa, foram analisadas as grades destas duas faculdades em questão com a grade da Universidade de São Paulo, que é referência em todo o país. E dentro destas grades, analisar as matérias que diretamente ou indiretamente contribuíram para a preparação como líderes.

Abaixo segue as disciplinas relacionadas com o foco da pesquisa nas três universidades, USP, UNIC E UNEMAT. É visível dentro das ementas a diferença entre os conteúdos e as quantidades de matérias relacionadas à liderança/gestão. Na USP, aonde é referência de ensino, a variedade de disciplinas são maiores ligadas a este tipo de desafio do acadêmico, além de possuir uma específica nesta área, a de "Liderança e Comportamento Humano" (figura 13). Na UNEMAT e na UNIC, possuem também disciplinas relacionadas, mas a quantidade é menor em relação a USP.

Quadro 03 - Disciplinas relacionadas à gestão/liderança - USP

\begin{tabular}{|c|c|c|c|}
\hline Disciplinas & $\begin{array}{l}\text { Carga } \\
\text { Horária }\end{array}$ & $\begin{array}{l}\text { Conteúdo Relacionado à } \\
\text { gestão/liderança }\end{array}$ & Método de Ensino \\
\hline $\begin{array}{l}\text { Ambientes } \\
\text { de Negócios }\end{array}$ & 30 horas & $\begin{array}{l}\text { Contexto sócio-econômico e cultural } \\
\text { brasileiro. Ambiente de negócios no } \\
\text { Brasil. Aspectos legais e formais } \\
\text { influenciando organizações e negócios. } \\
\text { Economia e Mercado. Setores Agrícolas, } \\
\text { Industrial, e de Serviços. Inflação, juros e } \\
\text { câmbio. Planejamento e controle nas } \\
\text { organizações. Gestão de pessoas e } \\
\text { desenvolvimento de talentos. }\end{array}$ & $\begin{array}{l}\text { De acordo com o escopo da disciplina } \\
\text { envolvendo abordagem conceitual } \\
\text { (aulas expositivas com discussões) e } \\
\text { prática (visitas, observações em } \\
\text { campo), a avaliação é composta por } \\
\text { elementos formativos e sumativos. }\end{array}$ \\
\hline $\begin{array}{l}\text { Comportam } \\
\text { ento } \\
\text { Organizacio } \\
\text { nal }\end{array}$ & 60 horas & $\begin{array}{lcr}\text { Estudo dos múltiplos aspectos } & \text { do } \\
\text { comportamento } & \text { humano } & \text { nas } \\
\text { organizações, liderança e poder. } & \end{array}$ & $\begin{array}{l}\text { Aulas expositivas com apresentação da } \\
\text { teoria combinada com a resolução de } \\
\text { problemas. Exercícios para fixação dos } \\
\text { conhecimentos adquiridos. }\end{array}$ \\
\hline $\begin{array}{l}\text { Jogos de } \\
\text { Empresas I } \\
\text { (Business } \\
\text { Game) }\end{array}$ & 60 horas & $\begin{array}{l}\text { Propiciar a simulação dos conceitos e } \\
\text { práticas contábeis inerentes à gestão } \\
\text { empresarial, numa abordagem básica. }\end{array}$ & $\begin{array}{l}\text { Apresentação da teoria combinada } \\
\text { com a resolução de problemas. } \\
\text { Exercícios para fixação dos } \\
\text { conhecimentos adquiridos. }\end{array}$ \\
\hline $\begin{array}{l}\text { Jogos de } \\
\text { Empresas II } \\
\text { (Business } \\
\text { Game) }\end{array}$ & 60 horas & $\begin{array}{l}\text { Propiciar a simulação dos conceitos e } \\
\text { práticas contábeis inerentes à gestão } \\
\text { empresarial, numa abordagem básica. }\end{array}$ & $\begin{array}{l}\text { Apresentação da teoria combinada } \\
\text { com a resolução de problemas. } \\
\text { Exercícios para fixação dos } \\
\text { conhecimentos adquiridos. }\end{array}$ \\
\hline $\begin{array}{l}\text { Liderança e } \\
\text { Comporta } \\
\text { mento }\end{array}$ & 30 horas & $\begin{array}{l}\text { Refletir sobre a condição social do ser } \\
\text { humano e suas implicações na } \\
\text { organização do trabalho como atividade } \\
\text { grupal. Discutir o conceito de }\end{array}$ & $\begin{array}{l}\text { Aulas expositivas e aulas dialogadas, } \\
\text { discussões em grupo, através de } \\
\text { variadas dinâmicas. }\end{array}$ \\
\hline
\end{tabular}


Nível de preparação para liderança, sob a perspectiva dos acadêmicos de ciências contábeis da UNEMAT

e UNIC em Tangará da Serra - formandos 2013/2

Ana Caroline Bastos Casagrande

Ivon de Mello Trelha

\begin{tabular}{|l|l|l|l|}
\hline Humano & $\begin{array}{l}\text { liderança. Analisar o gerenciamento } \\
\text { como uma atividade de articulação } \\
\text { grupal e de influência sobre grupos. }\end{array}$ & \\
\hline
\end{tabular}

Fonte: Universidade de São Paulo, 2013.

Figura 14 - Disciplinas relacionadas à gestão/liderança - UNIC

\begin{tabular}{|c|c|c|c|}
\hline Disciplinas & $\begin{array}{c}\text { Carga } \\
\text { Horária }\end{array}$ & $\begin{array}{l}\text { Conteúdo Relacionado à } \\
\text { gestão/liderança }\end{array}$ & Método de Ensino \\
\hline $\begin{array}{l}\text { Gestão } \\
\text { Empresarial }\end{array}$ & 60 horas & \begin{tabular}{llrr} 
Compreender & o & objeto & da \\
administração, & conceituando & e \\
distinguindo & as & suas principais \\
abordagens teóricas, diferenciando os \\
processos & \multicolumn{2}{c}{ administrativos } & e \\
relacionando & os & conhecimentos \\
adquiridos & com & a & prática \\
administrativa. & & &
\end{tabular} & $\begin{array}{l}\text { Exercícios referentes ao conteúdo } \\
\text { teórico, trabalhos individuais e em } \\
\text { grupos incluindo a elaboração de } \\
\text { artigos, discussão de textos, } \\
\text { apresentação de seminários e pesquisas. } \\
\text { Aulas expositivas, demonstrativas e } \\
\text { interativas. Aulas Expositivas com uso } \\
\text { de livros, retroprojetor, projetor de } \\
\text { multimídia, lousa e pincel; Aulas } \\
\text { demonstrativas no Laboratório de } \\
\text { Informática; Apresentação } \\
\text { seminários e pesquisas. }\end{array}$ \\
\hline $\begin{array}{l}\text { Psicologia } \\
\text { Organizacio } \\
\text { nal }\end{array}$ & 60 horas & $\begin{array}{l}\text { Principais abordagens em Psicologia } \\
\text { Organizacional. Análise das } \\
\text { organizações. Motivação e liderança. } \\
\text { Comportamento humano nas } \\
\text { organizações. Inteligência. Processo de } \\
\text { mudança. Relacionamento interpessoal. } \\
\text { Tendências. }\end{array}$ & $\begin{array}{l}\text { Diante da necessidade do processo de } \\
\text { avaliação oferecer possibilidades de } \\
\text { analisar criticamente o processo ensino- } \\
\text { aprendizagem, individual e coletivo, } \\
\text { serão utilizadas as seguintes } \\
\text { modalidades de avaliação: avaliação } \\
\text { escrita individual, com componentes } \\
\text { objetivos e subjetivos, trabalho escrito } \\
\text { individual, com consulta ao material } \\
\text { didático, trabalho escrito em grupo, sob } \\
\text { orientação do docente. }\end{array}$ \\
\hline
\end{tabular}

Fonte: Universidade de Cuiabá, 2013.

Quadro 04 - Disciplinas relacionadas à gestão/liderança - UNEMAT

\begin{tabular}{|c|c|c|c|}
\hline Disciplinas & $\begin{array}{l}\text { Carga } \\
\text { Horária }\end{array}$ & $\begin{array}{l}\text { Conteúdo Relacionado à } \\
\text { gestão/liderança }\end{array}$ & Método de Ensino \\
\hline $\begin{array}{l}\text { Controladori } \\
\text { a }\end{array}$ & 60 horas & $\begin{array}{l}\text { Introdução à Controladoria. Visão } \\
\text { Sistêmica de Empresa. Modelos de } \\
\text { Gestão. } \\
\text { Integrada. Planejamento Estratégico. } \\
\text { GECON. } \\
\text { Trabalho a ser } \\
\begin{array}{l}\text { antroles desenvolvido pelos } \\
\text { alunos. }\end{array}\end{array}$ & $\begin{array}{l}\text { Aulas expositivas, discussões em sala } \\
\text { de aula, exercícios para fixação das } \\
\text { práticas, trabalhos individuais ou em } \\
\text { grupo dentro e fora da sala de aula, } \\
\text { apresentação de seminários. }\end{array}$ \\
\hline $\begin{array}{l}\text { Gestão de } \\
\text { Pessoas }\end{array}$ & 60 horas & $\begin{array}{l}\text { Aspectos básicos do desenvolvimento } \\
\text { de pessoas na organização. Relações } \\
\text { Interpessoais. Aspectos básicos da } \\
\text { administração } \\
\text { Identificação, Recrutamento e Seleção } \\
\text { de Recursos Humanos, Cargos e } \\
\text { Salários e Benefícios, Planejamento e } \\
\text { Controle de Recursos Humanos. } \\
\text { Treinamento e Avaliação de } \\
\text { desempenho humano. O Processo de }\end{array}$ & $\begin{array}{l}\text { Aulas expositivas, dinâmicas, } \\
\text { musicais, estudos de caso, leituras, } \\
\text { vídeos motivacionais, micro-aulas } \\
\text { filmadas. }\end{array}$ \\
\hline
\end{tabular}


Nível de preparação para liderança, sob a perspectiva dos acadêmicos de ciências contábeis da UNEMAT

e UNIC em Tangará da Serra - formandos 2013/2

Ana Caroline Bastos Casagrande

Ivon de Mello Trelha

\begin{tabular}{|c|c|c|c|}
\hline & & Entrevista. & \\
\hline $\begin{array}{l}\text { Jogos de } \\
\text { Empresas }\end{array}$ & 60 horas & $\begin{array}{l}\text { Atividade de ensino realizada em } \\
\text { Laboratório através de Sistema } \\
\text { Integrado de Simulação Empresarial, } \\
\text { no ramo Industrial. }\end{array}$ & $\begin{array}{l}\text { Não estava disponível no departamento } \\
\text { de Ciências Contábeis. }\end{array}$ \\
\hline $\begin{array}{l}\text { Psicologia } \\
\text { Organizacio } \\
\text { nal }\end{array}$ & 60 horas & $\begin{array}{l}\text { O indivíduo humano como um ser } \\
\text { social. As organizações e suas } \\
\text { complexidades. Teorias que reguem o } \\
\text { comportamento organizacional do ser } \\
\text { humano. Os grupos. Liderança. } \\
\text { Eficiência e Motivação. A } \\
\text { comunicação nas organizações. } \\
\text { Treinamento. Recrutamento e Seleção. } \\
\text { Avaliação e desempenho. A neurose } \\
\text { profissional. }\end{array}$ & $\begin{array}{l}\text { Aulas expositivas, análise e discussão } \\
\text { de filmes, leitura e discussão de textos, } \\
\text { dinâmica de grupo, estudo de caso, } \\
\text { seminário. }\end{array}$ \\
\hline
\end{tabular}

Fonte: Universidade do Estado de Mato Grosso, 2013.

Levando em consideração que na UNEMAT está se passando por um momento de transição de grade curricular no período 2013/2, foi analisada a grade que vigorará em 2014. E pode-se constatar que apresentou mudanças significativas nas ementas das disciplinas que continuarão na grade, tais como: controladoria, psicologia organizacional e gestão de pessoas, conforme figura 14, além de acrescentar disciplinas eletivas voltadas ao tema da pesquisa. Porém toda a grade ainda esta em fase de reestruturação, só existe a disponibilidade do escopo, os métodos de ensino e formas de avaliação ainda estão sendo desenvolvidas pelo campus.

Dessa forma, após entrar em vigor, poderá dar prosseguimento a esta pesquisa, juntamente com os acadêmicos que irão cursar a nova grade, objetivando analisar as melhorias e resultado satisfatórios que houve em relação às ementas alteradas. Até o momento cabe ao Colegiado de Curso, semestralmente, definir quais disciplinas, do rol de eletivas, serão ofertadas, sendo dez por semestre, podendo também analisar na continuidade do trabalho a possibilidade dos acadêmicos participarem desta seleção, e assim poder cursar além das que são específicas da grade de Ciências Contábeis, outras disciplinas que possuem interesse, inclusive nas áreas de gestão.

Quadro 05 - Nova grade curricular 2014 - UNEMAT

\begin{tabular}{|c|c|c|c|}
\hline Disciplinas & $\begin{array}{c}\text { Carga } \\
\text { Horária }\end{array}$ & $\begin{array}{l}\text { Conteúdo Relacionado à } \\
\text { gestão/liderança }\end{array}$ & Método de Ensino \\
\hline $\begin{array}{l}\text { Controladori } \\
\text { a }\end{array}$ & 60 horas & \begin{tabular}{lcccr} 
Controladoria & \multicolumn{2}{c}{ nas } & \multicolumn{2}{c}{ organizações. } \\
Teorias aplicadas à & \multicolumn{2}{c}{ controladoria: } \\
institucional, & da & agência & e \\
contingência. & As & funções & do \\
Controller e & sua & posição & na
\end{tabular} & A desenvolver pela universidade \\
\hline
\end{tabular}


Nível de preparação para liderança, sob a perspectiva dos acadêmicos de ciências contábeis da UNEMAT

e UNIC em Tangará da Serra - formandos 2013/2

Ana Caroline Bastos Casagrande

Ivon de Mello Trelha

\begin{tabular}{|c|c|c|c|}
\hline & & $\begin{array}{l}\text { organização. Modelo e processo de } \\
\text { gestão. Fases de controle empresarial: } \\
\text { Planejamento Estratégico, Operacional } \\
\text { e controle orçamentário (Abordagem } \\
\text { conceitual), Execução } \text { (gestão } \\
\text { operacional. Ciclos: operacional, } \\
\text { econômico e financeiro. Gestão do } \\
\text { capital de giro. Gestão do imobilizado) } \\
\text { e Controle (Análise financeira, } \\
\text { Resultado dos detores } \\
\text { latividades/Divisional, Preços de } \\
\text { transferência, EVA-Valor Econômico } \\
\text { Adicionado, Gestão Econômica). }\end{array}$ & \\
\hline $\begin{array}{l}\text { Fundamento } \\
\text { s da } \\
\text { Administraç } \\
\text { ão }\end{array}$ & 60 horas & 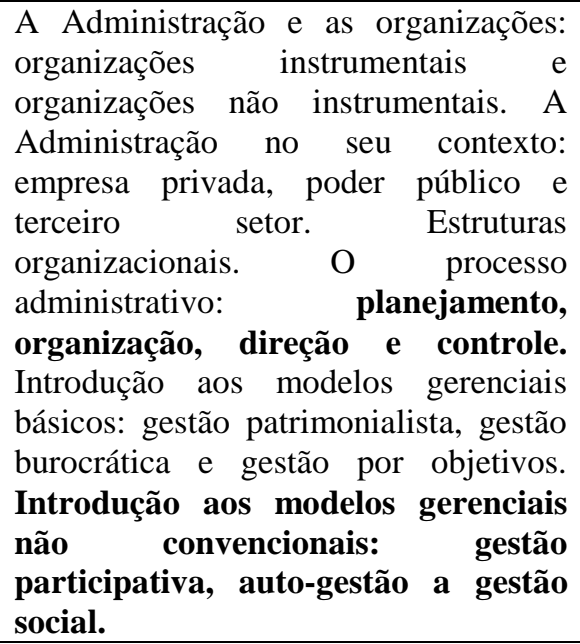 & $\begin{array}{l}\text { A desenvolver pela universidade } \\
\text { (Alteração da disciplina Teoria Geral da } \\
\text { Administração) }\end{array}$ \\
\hline $\begin{array}{l}\text { Gestão da } \\
\text { Informação, } \\
\text { do } \\
\text { conheciment } \\
\text { o e da } \\
\text { inteligência } \\
\text { organizacio } \\
\text { nal. } \\
\text { (Eletiva) }\end{array}$ & 60 horas & 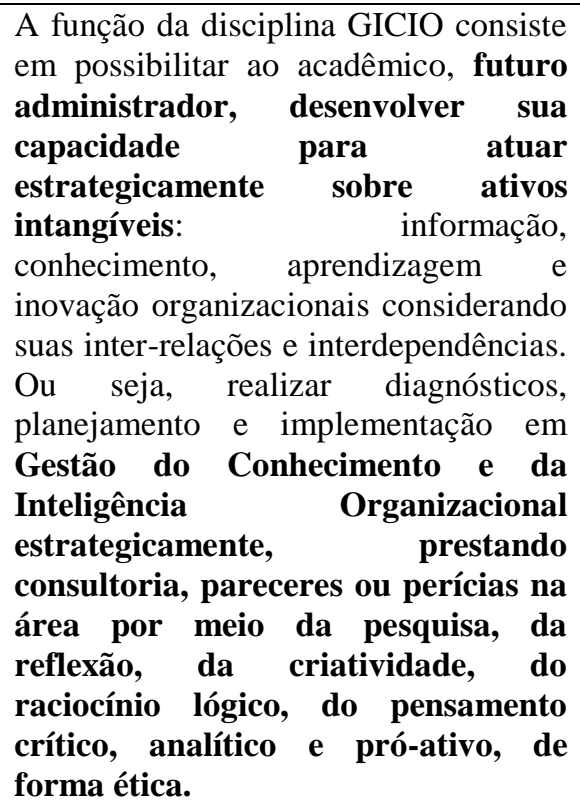 & A desenvolver pela universidade \\
\hline $\begin{array}{l}\text { Psicologia } \\
\text { do trabalho }\end{array}$ & 60 horas & $\begin{array}{l}\text { Contextualização histórica } \text { da } \\
\text { Psicologia. O desenvolvimento da } \\
\text { Psicologia do Trabalho. A psicologia e } \\
\text { suas concepções de homem. O } \\
\text { indivíduo as organizações e suas } \\
\text { complexidades. As relações humanas } \\
\text { no trabalho. Processo de liderança. } \\
\text { Funcionamento e desenvolvimento } \\
\text { de grupos. Motivação. Comunicação } \\
\text { nas organizações. }\end{array}$ & A desenvolver pela universidade \\
\hline
\end{tabular}


Nível de preparação para liderança, sob a perspectiva dos acadêmicos de ciências contábeis da UNEMAT

e UNIC em Tangará da Serra - formandos 2013/2

Ana Caroline Bastos Casagrande

Ivon de Mello Trelha

\begin{tabular}{|c|c|c|c|}
\hline $\begin{array}{l}\text { Consultoria } \\
\text { (Eletiva) }\end{array}$ & 60 horas & $\begin{array}{l}\text { Conceito de consultoria, importância } \\
\text { da consultoria, profissão do consultor, } \\
\text { fases da consultoria, ferramentas de } \\
\text { consultoria. }\end{array}$ & A desenvolver pela universidade \\
\hline $\begin{array}{l}\text { Contabilom } \\
\text { etria } \\
\text { (Eletiva) }\end{array}$ & 60 horas & 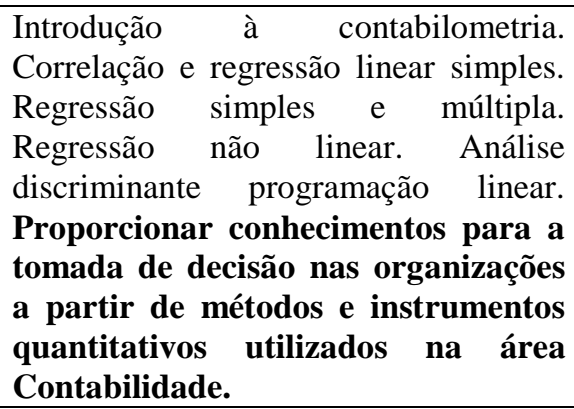 & A desenvolver pela universidade \\
\hline $\begin{array}{l}\text { Controle } \\
\text { Gerencial } \\
\text { (Eletiva) }\end{array}$ & 60 horas & $\begin{array}{l}\text { Natureza e conceituação do processo } \\
\text { de controle gerencial. Estratégia: } \\
\text { Conceituação e aplicabilidades. } \\
\text { Comportamento: O } \\
\text { econômico, o indivíduo } \\
\text { Poder nas organizações. Desenho das } \\
\text { organizações: Divisão do trabalho e } \\
\text { coordenação, Centros de } \\
\text { responsabilidade, Instrumentos e } \\
\text { mecanismos de coordenação, } \\
\text { Supervisão direta e ajustamento } \\
\text { mútuo, Controle de entrada, de } \\
\text { processos e de resultados, Cultura } \\
\text { Organizacional, Aplicando o } \\
\text { planejamento estratégico e operacional. } \\
\text { Sistemas Diagnósticos (mensuração de } \\
\text { desempenho). Sistemas Interativos: } \\
\text { Atribuição e cobrança de } \\
\text { responsabilidade, } \\
\text { Repensando o indivíduo nas } \\
\text { organizações a Organização como um } \\
\text { sistema dinâmico. }\end{array}$ & A desenvolver pela universidade \\
\hline $\begin{array}{l}\text { Gestão de } \\
\text { Pessoas I } \\
\text { (Eletiva) }\end{array}$ & 60 horas & $\begin{array}{l}\text { Introdução a Moderna Gestão de } \\
\text { Pessoas. Gestão de Pessoas em um } \\
\text { ambiente Dinâmico e Competitivo. } \\
\text { Processo Administrativo de Gestão de } \\
\text { Pessoas: Recrutamento e Seleção. } \\
\text { Orientação, Modelagem do Trabalho. } \\
\text { Avaliação de de Desempenho. } \\
\text { Remuneração. Programas de } \\
\text { Incentivos e Benefícios e Serviços. }\end{array}$ & A desenvolver pela universidade \\
\hline $\begin{array}{l}\text { Gestão de } \\
\text { Pessoas II } \\
\text { (Eletiva) }\end{array}$ & 60 horas & $\begin{array}{l}\text { Processo Administrativo de Gestão de } \\
\text { pessoas (GP). Desenvolver Pessoas: } \\
\text { Treinamento, Desenvolvimento de } \\
\text { Pessoas e Desenvolvimento } \\
\text { Organizacional. Manter pessoas: } \\
\text { Saúde, Higiene e Segurança no } \\
\text { trabalho, Qualidade de Vida e Relações } \\
\text { Sindicais. Monitorar pessoas: Banco } \\
\text { de Dados e Sistemas de Informações } \\
\text { Gerenciais de RH. Plano estratégico de } \\
\text { gestão de pessoas. O papel do } \\
\text { comunicador. O papel do coach. }\end{array}$ & A desenvolver pela universidade \\
\hline $\begin{array}{l}\text { Jogos de } \\
\text { Empresas }\end{array}$ & 60 horas & 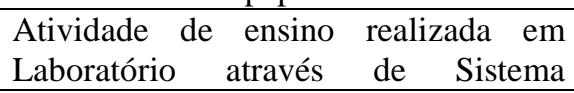 & A desenvolver pela universidade \\
\hline
\end{tabular}

Volume 3, Número 5

Revista UNEMAT de Contabilidade

Jan./Jun. 2014

UNEMAT 
Nível de preparação para liderança, sob a perspectiva dos acadêmicos de ciências contábeis da UNEMAT

e UNIC em Tangará da Serra - formandos 2013/2

Ana Caroline Bastos Casagrande

Ivon de Mello Trelha

\begin{tabular}{|l|l|l|l|}
\hline (Eletiva) & & $\begin{array}{l}\text { Integrado de Simulação Empresarial, } \\
\text { no ramo Industrial. }\end{array}$ & \\
\hline $\begin{array}{l}\text { Simulação } \\
\text { Empresarial } \\
\text { (Eletiva) }\end{array}$ & 60 horas & $\begin{array}{l}\text { Possibilitar ao acadêmico uma } \\
\text { experiência real de tomada de decisões }\end{array}$ & A desenvolver pela universidade \\
& & $\begin{array}{l}\text { através da disciplina de Simulação } \\
\text { Empresarial. }\end{array}$ & \\
\hline
\end{tabular}

Fonte: Universidade do Estado de Mato Grosso, 2013.

\section{CONSIDERAÇÕES FINAIS}

A pesquisa foi desenvolvida com o objetivo geral de descobrir a preparação como líderes/gestores para o mercado de trabalho dos formandos do curso de Ciências Contábeis 2013/2 na UNEMAT - Universidade do Estado de Mato Grosso, e na UNIC - Universidade de Cuiabá.

Após a análise dos dados obtidos foi constatado que a grande maioria dos acadêmicos ainda não se sentem preparados para atuar na área de liderança/gestão. Além disso, eles julgavam que parte da responsabilidade era da própria universidade, devido à falta de prática das disciplinas do curso voltadas diretamente ou indiretamente para esta área.

A pretensão da grande maioria dos acadêmicos nas duas universidades é atuar na área pública, em segundo lugar na UNEMAT a pretensão era de trabalhar em escritório contábil e na UNIC eles não pretendiam atuar na área que cursou durante o período acadêmico.

Diante da problemática levantada pelos acadêmicos em relação à falta de aplicação da prática das disciplinas, se fez necessário a análise das grades curriculares das duas universidades comparando-as com a USP, referência em todo o Brasil, e pode-se constatar que elas te uma grande diferença, principalmente nas disciplinas voltadas para a área de gestão/liderança.

Porém, a UNEMAT esta em processo de transição de grade curricular, e analisando a nova grade, a proposta de ensino voltada para área de gestão/liderança para 2014 houve grandes mudanças satisfatórias, adicionando matérias eletivas obrigatórias e específicas nestas áreas.

Torna-se pertinente uma analise futura mais detalhada com os acadêmicos que irão cursar a nova grande da UNEMAT em 2014, para verificar se realmente estas ementas alteradas na grade terão efeitos positivos para os acadêmicos que pretendem atuar em cargos de gestão/liderança. 
Nível de preparação para liderança, sob a perspectiva dos acadêmicos de ciências contábeis da UNEMAT e UNIC em Tangará da Serra - formandos 2013/2

Ana Caroline Bastos Casagrande

Ivon de Mello Trelha

\section{REFERÊNCIAS BIBLIOGRÁFICAS}

AQUINO, Isa Raquel Lebre de Oliveira. Artigo: Perfil profissional do contador da atualidade: perfil empreendedor. Faculdade Vale do Itapecuru - FAI, 2010.

BOOG, Gustavo \& Magdalena. Manual de gestão de pessoas e equipes. $1^{\text {a }}$ edição - Editora: Gente, São Paulo, 2002.

CECCON, Jackson José. Artigo - Os Conhecimentos, Habilidades e Atitudes necessárias aos Novos Gestores em suas Tomadas de Decisão, 2011.

COELHO, Tom. Liderança e Poder. Disponível em:

http://www.tomcoelho.com/index.aspx/s/Artigos_Exibir/105/Lideranca_e_poder. Acesso em 01/09/2013.

DUTRA, Joel Souza, HIPÓLITO, José Antônio Monteiro, SILVA, Cassiano Machado. Gestão de pessoas por competências: o caso de uma empresa do setor de telecomunicações. IN. Anais do 22o encontro da Associação Nacional dos Programas de Pósgraduação em Administração - ENANPAD. Foz do Iguaçu: ANOAD, 1998.

DUTRA, Joel de Souza. Gestão de Competências. São Paulo: Ed. Gente, 2001

FACHADA, Odete. Psicologia das relações interpessoais . Lisboa: Edições Rumo, lda, 1998.

GIL, Antônio Carlos. Métodos e técnicas de pesquisa social. 5. ed. São Paulo: Atlas, 2002.

GONDIN, Sonia Maria Guedes. Artigo - Perfil profissional e mercado de trabalho: relação com a formação acadêmica pela perspectiva de estudantes universitários, 2002.

IUDÍCIBUS, Sérgio de e MARTINS, Eli seu. Contabilidade: uma visão crítica e o caminho para o futuro. São Paulo: CRCSP, 1990.

JUNG, Carlos Fernando. Metodologia para pesquisa e desenvolvimento. Rio de Janeiro: Axcel Books, 2004.

KounRouZAN, Márcia Covaciuc. 0 Perfil do Profissional Contábil, 2011. Disponível em: http://www.oswaldocruz.br Acesso em: 12/11/2013

Lei de Diretrizes e Base da Educação Brasileira, No 9.394, de 20 de dezembro de 1996 Disponível em: http://portal.mec.gov.br/arquivos/pdf/ldb.pdf. Acesso em: 15/11/2013

LIMA, Renata Fernandes de Oliveira - Artigo: Gestão Estratégica de Pessoas: uma ferramenta poderosa -2010 .

MATRIZ CURRICULAR DE CIÊNCIAS CONTÁBEIS - Universidade de São Paulo Disponível em:

https://uspdigital.usp.br/jupiterweb/listarGradeCurricular?codcg=12\&codcur=12033\&codhab $=4 \&$ tipo $=\mathrm{N}-$ Acesso em: $14 / 11 / 2013$ 
Nível de preparação para liderança, sob a perspectiva dos acadêmicos de ciências contábeis da UNEMAT e UNIC em Tangará da Serra - formandos 2013/2

Ana Caroline Bastos Casagrande Ivon de Mello Trelha

MATRIZ CURRICULAR DE CIÊNCIAS CONTÁBEIS - Universidade de Cuiabá Disponível em: http://www.unic.br/Paginas/home.aspx - Acesso em: 14/11/2013

MATRIZ CURRICULAR DE CIÊNCIAS CONTÁBEIS - Universidade do Estado de Mato Grosso - Disponível em: http://www2.unemat.br/ - Acesso em: 14/11/2013

MAXWELL, John C. O Livro de ouro da liderança. Editora Thomas Nelson Brasil, 2008.

NASI, Antônio. A Contabilidade como Instrumento de Informações, Decisão e Controle da Gestão. Revista Brasileira de Contabilidade. Brasília. №77. Abril/Junho, 1994.

PROJETO PEDAGÓGICO DO CURSO DE CIÊNCIAS CONTÁBEIS - Campus Universitário de Tangará da Serra - 2012 - Disponível em: https://sites.google.com/a/unemat.br/cictga/home

RANKING UNIVERSITÁRIO DA FOLHA 2013 - Disponível em:

http://ruf.folha.uol.com.br/2013/rankinguniversitariofolha - Acesso em: 14/11/2013

RUANO, Alessandra Martinewski. Gestão por competências - Uma perspectiva para a consolidação da gestão estratégica de recursos humanos. Ed. Qualitymark, São Paulo, 2003.

SOVIENSKI , Fernanda; STIGAR, Robson. Artigo: Recursos humanos X Gestão de pessoas, 2008.

VERGARA, S. M. Projetos e relatórios de pesquisa em administração. São Paulo: Atlas, 1997.

ZANLUCA, Julio César. Artigo: O perfil profissional do contabilista do século XXI Disponível em: http://www.portaldecontabilidade.com.br/noticias/perfil_contador.htm Acesso em: 15/11/2013. 